\title{
In memoriam: Vladyslav Povoroznyuk
}

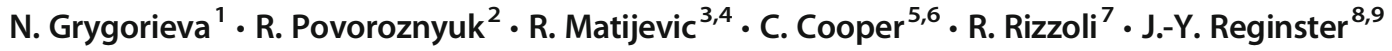

Published online: 28 July 2021

(C) International Osteoporosis Foundation and National Osteoporosis Foundation 2021

\section{In memoriam: Vladyslav Povoroznyuk}

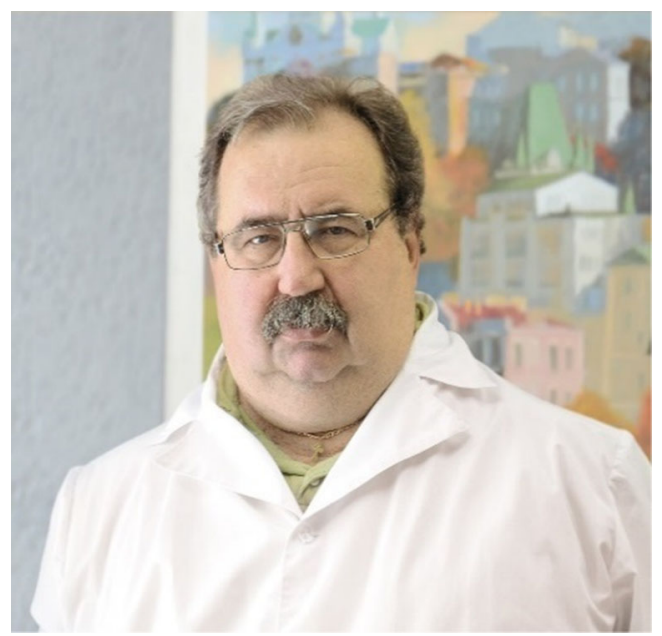

The Ukrainian Association of Osteoporosis, its members and international colleagues are mourning the sudden death of Professor Vladyslav Povoroznyuk, who passed away on June 12, 2021, at the age of 66 years.

\section{R. Matijevic}

RADMILA.MATIJEVIC@mf.uns.ac.rs

1 Department of Clinical Physiology\&Pathology of Locomotor Apparatus, Dmytro F. Chebotarov Institute of Gerontology of the National Academy of Medical Sciences of Ukraine, Kyiv, Ukraine

2 Department of Theory and Practice of Translation from English, Institute of Philology, Taras Shevchenko National University of Kyiv, Kyiv, Ukraine

3 Department for Medical rehabilitation, Medical faculty, University of Novi Sad, Novi Sad, Serbia

4 Orthopaedic and Trauma Clinic, Clinical Centre of Vojvodina, Novi Sad, Serbia
He has served as the President of the Ukrainian Association of Osteoporosis; President of the Ukrainian Association of Andropause, Menopause, Bone and Joint Disease; Head of the Ukrainian Division of the European Vitamin D Association (EVIDAS); Head of the Department of Clinical Physiology and Pathology of the Locomotor Apparatus of the Dmitry F. Chebotarev Institute of Gerontology of the National Academy of Medical Sciences of Ukraine; Director of the Ukrainian Scientific Medical Centre of Osteoporosis; the Honoured Scientist and Technology Expert of Ukraine; and as the Editor-in-Chief of the "Pain. Joints. Spine" and "Problems of Osteology" journals.

Professor V.V. Povoroznyuk started his scientific career at the Institute of Gerontology (Kyiv, Ukraine). In 1988, he defended his $\mathrm{PhD}$ thesis, and in 1999 went on to defend his doctoral thesis "Osteoporosis in the Ukrainian population: risk factors, clinic, diagnostics, and treatment”. From 1992 until the last days of his life, he headed the Department of Clinical Physiology and Pathology of the Locomotor Apparatus.

In 1996, Professor V.V. Povoroznyuk led the creation of the Ukrainian Association of Osteoporosis and was elected its founding president. In 1998, under the aegis of the Association, he founded the Ukrainian Scientific-Medical Centre of Osteoporosis providing medical consultations and treatment to people all over the country. Furthermore,

5 MRC Lifecourse Epidemiology Unit, University of Southampton, Southampton, UK

6 NIHR Musculoskeletal Biomedical Research Unit, University of Oxford, Oxford, UK

7 Service of Bone Diseases, Geneva University Hospitals and Faculty of Medicine, Geneva, Switzerland

8 Department of Public Health, Epidemiology and Health Economics, University of Liège, Liège, Belgium

9 Chair for Biomarkers of Chronic Diseases, Biochemistry Department, College of Science, King Saud University, Riyadh, Kingdom of Saudi Arabia 
Professor V.V. Povoroznyuk initiated the creation of the Patients' Society "Ukraine without osteoporosis and fractures".

Professor V.V. Povoroznyuk's range of academic interests included epidemiology, pathogenesis, diagnostic, prevention and treatment of locomotor disorders; age-related changes in physical performance; and the influence of accompanying pathologies in various organs and systems.

Vladyslav Povoroznyuk launched the definitive Ukrainian epidemiological study of various population groups affected by osteoporosis and its complications. The objectives of this study included exploring determinants of peak bone mass in Ukrainian children and adolescents and characterising the rates of bone loss among men and women of various ages. $\mathrm{He}$ masterminded the creation of a reference bone tissue database for the Ukrainian population. Professor V.V. Povoroznyuk initiated an epidemiological study of vitamin D insufficiency among the Ukrainian population and its influence on the musculoskeletal axis. Professor V.V. Povoroznyuk also conducted a series of trabecular bone score (TBS) studies, providing the normative TBS parameters for Ukrainian people of various ages. He pioneered sarcopenia studies in Ukraine establishing the parameters of skeletal muscle mass and function for women belonging to various age groups, sarcopenia's developmental mechanisms, "cut-off" points for low muscle mass and the prevalence of sarcopenia among older women.

Professor VV. Povoroznyuk promoted development of sister osteoporosis societies in Moldova, Belarus and other countries.

He was an author/co-author of around 800 articles, twenty monographs and national guidelines and contributed to allEuropean publications including "New Europe: Consensus on Osteoporosis" (2003) and "The Eastern European \& Central Asian Regional Audit: Epidemiology, costs \& burden of osteoporosis in 2010".

Professor VV. Povoroznyuk made a significant contribution to the locomotor apparatus diseases study, as well as the overall development of gerontology in Ukraine. He was a world-renowned scientist and will be missed by his family, colleagues and friends not only in Ukraine but all over the world.

Publisher's note Springer Nature remains neutral with regard to jurisdictional claims in published maps and institutional affiliations. 